This is an electronic reprint of the original article. This reprint may differ from the original in pagination and typographic detail.

Author(s): Laine, Kati; Hämäläinen, Raija

Title: $\quad$ Collaborative business planning in initial vocational education and training

Year: $\quad 2015$

Version:

Please cite the original version:

Laine, K., \& Hämäläinen, R. (2015). Collaborative business planning in initial vocational education and training. Journal of Vocational Education and Training, 67(4), 497-514. https://doi.org/10.1080/13636820.2015.1063000

All material supplied via JYX is protected by copyright and other intellectual property rights, and duplication or sale of all or part of any of the repository collections is not permitted, except that material may be duplicated by you for your research use or educational purposes in electronic or print form. You must obtain permission for any other use. Electronic or print copies may not be offered, whether for sale or otherwise to anyone who is not an authorised user. 


\section{Collaborative Business Planning in Initial Vocational Education and Training}

\section{Introduction}

There is a growing need at a global level to promote creativity, innovation and self-employment (European Commission, Enterprise and Industry Directorate-General 2009). Therefore, the increasing demand for entrepreneurship and the enhancement of entrepreneurial skills has been one of the most significant changes, in terms of the skills required, for today's work environment. These requirements have also reshaped the curricula of initial vocational education and training (iVET) programmes. Entrepreneurship education has been included, at least to some extent, in the national core curricula of iVET in the majority of European countries. While programmes and activities are many and varied in this field, the general perception is that there is still a gap to be filled, mainly in regard to limited student participation, ineffective teaching methods and the absence of links between entrepreneurship and specific training subjects (European Commission, Enterprise and Industry Directorate-General 2009).

It is argued that the core competencies of entrepreneurs, such as creating business plans, should be enhanced in education (European Centre for the Development of Vocational Training 2011). Even if young people do not become entrepreneurs after they complete school, entrepreneurship education may familiarise them with enterprising attitudes and behaviour. Entrepreneurship education is linked with career and vocational guidance, particularly in the sense that it is the responsibility of the education system to expose students to a broad range of career options, including entrepreneurship (Onstenk 2003; European Centre for the Development of Vocational Training 2011). 
This study examines entrepreneurship education in the context of iVET, and in doing so it focusses on a process aimed at enhancing the learning of entrepreneurship by integrating collaborative learning into the drafting of a business plan. The process is further enhanced by a computer-supported learning environment. By examining the combined development of entrepreneurial, social and ICT skills, this study contemplates the important European aim of enhancing the status of transversal key competencies, which refer to competencies that help people to adapt to changes and enhance their occupational mobility, compared to traditional subject-based competencies (European Commission/EACEA/Eurydice 2012).

\subsection{Emphasis on entrepreneurship education}

In the context of education, two main approaches to entrepreneurship can be identified. The first approach understands entrepreneurship as the establishment and running of a business, where the focus is on business studies and the teaching of management skills (for example, business planning and budgeting). The second, broader approach aims to promote the learning of enterprising capabilities, such as innovativeness, networking and collaboration skills, initiative and self-confidence, all of which can be utilised in multiple contexts and not purely in business (Gibb 2005; Kirby 2007). In addition to making a distinction between these two types of entrepreneurship (Gibb 2005; Kirby 2007; Leffler 2009), three main learning objectives of entrepreneurship education have been defined: learning to understand entrepreneurship, learning to become entrepreneurial and learning to become an entrepreneur (Heinonen and Poikkijoki 2006). 
The emphasis placed on each objective varies within and between different types of education programmes, but the dominant pattern of entrepreneurship education has had its focus on starting up and running a business (Liñán 2007), particularly in learning the competences necessary to become an entrepreneur. These start-up programmes are commonly based on the development of a business plan (Honig 2004; Liñán 2007). A business plan can be understood as a business opportunity in its most elaborated form (Ardichvili, Cardozo and Ray 2003). Such a plan articulates the merits, requirements, risks and potential rewards relating to the opportunity and how it can be grasped (Timmons and Spinelli 2009). Business planning is believed to increase the knowledge, skills and comprehension that can assist entrepreneurs in the process of starting a firm (Honig 2004). When making a business plan, both the end product and the preparation process are important. During the process, the learner is forced to take a critical look at the entire business project, whereas the actual plan can serve as an operating tool for successful business management (Bangs 2002, 1).

\subsection{Collaborative learning approach}

In addition to entrepreneurial skills and knowledge, group problem-solving and collaboration skills are increasingly essential for the working environment (Tynjälä 2013). The advance of collaborative learning approaches has been highlighted by numerous researchers. According to Arvaja (2007), high-level collaboration is defined as the joint construction of knowledge through the sharing of ideas by all participants. A number of positive effects relating to this type of 'effective' group process have been reported in computer-supported collaborative learning (CSCL) settings; for example, enhanced 
conceptual understanding (Krange and Ludvigsen 2008). Additionally, collaborative learning is seen as an effective means for solving complex problems through productive learning activities, such as argumentation (Tsovaltzi et al. 2014) and reasoning (Mercer et al. 2004).

\subsubsection{Hinders and enablers of collaborative learning}

According to Krange and Ludvigsen (2008), the effectiveness of collaborative learning is affected by the quality of shared group processes. Therefore, in designing collaboration, there is a need to emphasize group processes that may hinder or assist collaboration between the participants (Ruiz-Primo, Figueroa and Gluckman 2011). According to Hämäläinen and Vähäsantanen (2011), three perspectives need to be considered in instructional design of collaboration processes: task structures (open ended, set tasks, structured and unstructured); interactions (research-based interaction beneficial for collaboration); and resources (internal, external and integrated). In particular, research findings have indicated that the preferable learning task should be project-like, problemand practically-oriented and require learners to take different points of view in order to foster their collaboration (Hron and Friedrich 2003). Additionally, the complexity of the learning task has been argued as an important factor in determining the effectiveness of collaborative learning (Kirschner, Paas and Kirschner 2009). Successful collaboration requires positive social interaction-a sense of community where people know and can trust each other, and feel they belong to the group-elements not directly related to the task itself (Kreijns, Kirschner and Jochems 2003). Finally, different learning resources can be used to trigger successful interactions in collaboration situations. For example, 
external resources (e.g., the Internet) and/or internal resources (such as learners' previous experiences) have been used beneficially to enhance collaboration processes (Arvaja 2012).

Collaborative learning process is formed of a complex combination of learning tasks, learning resources and environments, participants' cognitive systems, and the motivational and social factors. All these elements influence to the effectiveness of the learning process. (Kirschner, Paas and Kirschner 2009.) Without accurate support, learners may have difficulties in reaching mutual understanding (O'Bannon, Lubke and Britt 2013) and in engaging shared group processes (Hämäläinen and Häkkinen 2010). Previous research has pointed out factors that are likely to hinder the effectiveness of collaborative learning. Specifically, participants with few successful collaborative experiences may lack the necessary skills to collaborate (Fischer et al. 2013). As a result, collaborative learning may be disrupted by unequal participation (e.g., freeriding) (Strijbos and De Laat 2010), and simplistic participation methods (e.g., participation lacking a reciprocal questioning) (Hämäläinen and Häkkinen 2010). Effective collaboration may also be hindered by participants receiving too little information about the other team-members they are working with. Additionally, too-limited teacher presence in CSCL situations may hinder effective group activities (Stahl 2002). Therefore, the ability of teachers to enhance productive collaborative learning processes is a particular challenge when applying collaborative learning.

Previous findings have indicated that instructional scaffolding (a learning process designed to promote certain learning activity) is needed to generate successful collaborative learning. In line with this, prearranging learning situations using 
collaboration scripts, so as to naturally trigger teamwork, has been introduced as a way to bring about successful learning (for a detailed description see, Kobbe et al. 2007). Scripts are instructions that prescribe how participants should work together. Specifically, the aim is to trigger shared group processes that are expected to empower productive learning processes; for example, solving socio-cognitive conflicts (Fischer et al. 2013). A script typically comprises different phases, each of which can be defined in terms of the following five attributes: 1) task; 2) composition of the group; 3) distribution; 4) mode of interaction; and 5) timing (Dillenbourg 2002). The task encompasses the input, activity and output required during the phase in question. The composition and size of the group and the grounds for group formation may vary in different phases of learning. In terms of distribution, the input or activity and its contents can be distributed within the group (intra-group distribution) or between groups (inter-group distribution). The mode of interaction may refer, for example, to distance versus co-present activities, or to synchronous (communication takes place in real time) versus asynchronous interaction (no engagement to time; e.g., takes place through online learning resources). Interaction also indicates the different actors involved and their actions; for example, the feedback given by the teacher. Timing specifies the time constraints and deadlines (Dillenbourg 2002).

Several studies have reported the positive effects of scripts (review by Fischer et al. 2013). For example, scripted collaborative learning has been found to outperform individual learning (Weinberger, Stegmann and Fischer 2010). De Wever and colleagues (2015) have indicated that scripting also seems to be beneficial for triggering the use of learning resources. 


\section{Research task and questions}

This case study aims to find out how successfully vocational students can collaboratively develop a business plan. In relation to success, the study examines the factors that hindered the exercise and the factors which acted as enablers. The specific study questions were 1) What factors hindered the exercise? and 2) What factors acted as enablers? In addressing these questions, the study offers insights into the realities of VET, and assists in finding ways to combine CSCL and entrepreneurship education (European Commission/EACEA/Eurydice 2012).

\section{Methods}

\subsection{Context and learning task}

The context of this case study is Finnish iVET. This article is based on a research and development project which aims to improve personal and collaborative learning in initial vocational education through the introduction of a computer-supported learning environment. The environment for this project was based on the idea of personal learning environments (PLEs) (Attwell 2007), CSCL learning, and the needs of initial vocational education. The PLE is particularly valuable because access to the environment, its tools and its documents does not end when the student finishes school, but can continue thereafter as long as the student wishes.

This case study focusses on entrepreneurship education in the area of wood processing. Entrepreneurship education was chosen as a target of a more thorough examination because in iVET, and in the education system in general, there is a growing 
demand for the development of skills related to entrepreneurship (Neck \& Greene 2011; von Graevenitz, Harhoff \& Weber 2010). According to the teacher of the woodprocessing group, support for the area in the vocational education setting is currently weak. Thus, the value of this case lies in studying a relatively rare phenomenon-the opportunity to implement a CSCL -approach (Shaughnessy, Zechmeister and Zechmeister 2002), and learning from this unique situation.

The target group of this study included a group of eight first-year students (six male and two female) and their teacher in a course called "Vocational Qualification in Wood Processing” (a study programme in industrial joinery). In the study, a computersupported learning environment (Omatila) was implemented via the Internet. The learning environment included a 'personal space' (cf., PLE above) for every student, in which they were able to use different types of learning tools, including a blog, a folder for documents and a module for devising questionnaires. The scripted learning task (Kobbe et al. 2007) focussed on enhancing the students' entrepreneurial skills and knowledge of entrepreneurship by integrating collaborative learning with the process of devising a business plan.

The predefined structure of the learning task comprised a contact-learning period of two hours and a distance-learning period of 14 hours. Distance-learning took place on the school premises or in an informal learning environment such as the home of a student. As part of the learning task, the students used the blog to create an introductory business plan, first in pairs and then by commenting on the plans of the other pairs individually. Finally, the teacher judged which student pair had the best business plan so far. Individual students of the whole group, who at this stage played the holders of different 
key business roles (e.g., marketing director), then commented on the plan. The main themes and questions that the students were asked to take into account in their business plans were: the business idea (why does the business exist?); a description of the product or service (what does the business do in practice?); students' own skills and cooperation (can we implement the business idea in practice or do we need help from others?); customers (to whom does the business sell its products/services?); competitors (does someone else sell similar products/services?); and finance (how much money do we need, and where will the money come from?). Students were also introduced to a few net-based business-plan schemes. Through pondering the above questions, they were engaged to consider the whole business project critically (Bangs 2002).

In this learning task, the most obvious focus of entrepreneurship education was on learning to become an entrepreneur. However, the other objectives-learning to understand entrepreneurship and learning to become entrepreneurial—also play a very important role in iVET. The learning task included not just individual learning but learning with and from others, which is seen as typical for entrepreneurs (Gibb 2000). In this study, we will see business plan preparation as a learning process, and treat the role of the plan as an actual operating tool, with the possibility that the plan may be realised in the future. Therefore, the plan as an outcome of the learning process is examined from the viewpoint of entrepreneurship-related learning, rather than on how it is used as the foundation for an actual business operation.

In Table 1, each phase of the open-ended learning task is described by means of five main attributes (Dillenbourg 2002). These attributes help to structure the students' interaction and problem-solving activities, as well as the use of learning resources in the 
different phases of the task (Hämäläinen and Vähäsantanen 2011). In addition, the role of the teacher is taken into account.

TABLE 1: Phases of the scripted business-plan learning task

\begin{tabular}{|c|c|c|c|c|c|c|}
\hline $\begin{array}{c}\text { Phase / } \\
\text { attribute }\end{array}$ & Task & Group & Distribution & Interaction & Timing & $\begin{array}{c}\begin{array}{c}\text { Role of the } \\
\text { teacher }\end{array} \\
\end{array}$ \\
\hline Phase 1 & $\begin{array}{l}\text { To create a } \\
\text { business idea, } \\
\text { form a } \\
\text { business plan } \\
\text { and publish it } \\
\text { in a blog }\end{array}$ & Pair (x 4) & $\begin{array}{l}\text { Inter-pair } \\
\text { content } \\
\text { distribution }\end{array}$ & $\begin{array}{l}\text { Co-present, } \\
\text { (distant) }\end{array}$ & $\begin{array}{l}\text { 8-day time } \\
\text { limit + } \\
\text { deadline }\end{array}$ & \multirow{3}{*}{$\begin{array}{l}\text { - } \text { Monitoring } \\
\text { - Tutoring } \\
\text { - Regulating } \\
\text { learning by } \\
\text { commenting, } \\
\text { and giving } \\
\text { feedback by } \\
\text { writing } \\
\text { comments } \\
\text { on students' } \\
\text { blogs } \\
\text { - Evaluating } \\
\text { - Choosing } \\
\text { and } \\
\text { rewarding } \\
\text { the best } \\
\text { business } \\
\text { plan }\end{array}$} \\
\hline Phase 2 & $\begin{array}{l}\text { To give a } \\
\text { concrete } \\
\text { development } \\
\text { proposition for } \\
\text { the business } \\
\text { plan of another } \\
\text { pair by writing } \\
\text { it in their blog }\end{array}$ & Individual & $\begin{array}{l}\text { No } \\
\text { unambiguous } \\
\text { intra- or } \\
\text { inter-pair } \\
\text { distribution }\end{array}$ & Distant & $\begin{array}{l}\text { 7-day time } \\
\text { limit }+ \\
\text { deadline }\end{array}$ & \\
\hline Phase 3 & $\begin{array}{l}\text { To develop the } \\
\text { business plan } \\
\text { chosen as the } \\
\text { best from the } \\
\text { viewpoint of } \\
\text { different } \\
\text { developmental } \\
\text { roles*. At least } \\
\text { one concrete } \\
\text { development } \\
\text { proposition is } \\
\text { to be written } \\
\text { into the blog } \\
\text { by each student }\end{array}$ & Individual & $\begin{array}{l}\text { Intra-group } \\
\text { content } \\
\text { distribution }\end{array}$ & Distant & $\begin{array}{l}\text { 7-day time } \\
\text { limit + } \\
\text { deadline }\end{array}$ & \\
\hline
\end{tabular}

* Developmental key business roles were chosen by the students on a 'first come, first served' basis. The roles included financial director, marketing director, production manager, human resources manager, purchasing manager, customer service manager, research and development manager and quality manager.

In addition to the phases introduced in Table 1, a starting session (initial instructions from the teacher to the students) and an optional closing session (two-way feedback) were included in the learning task. 


\subsection{Data and analysis}

To track the hindrances and enablers of the collaborative learning process, a qualitative case-study approach was adopted. The case-study method allows the empirical investigation of a phenomenon in the context within which it occurs, thereby helping to reveal its essential features (Yin 2003). The study focusses more on understanding the case than on making generalisations beyond its scope (Stake 2005). Additionally, a design-based approach to an educational model based on theoretical principles was applied by integrating a collaboration script in the task (Hämäläinen and De Wever 2013).

The participating teacher and the eight students constituted two units of analysis: the students' activities and the teacher's activities and interpretation. The data included the students' and teacher's activities during the study process, the outcome of the process (a business plan), and the teacher's perspective on the students' work. The data comprised video and live observations made by the researcher during the starting and closing sessions, outputs and discussions written by the students and the teacher in the learning environment, a voice recording of a student pair during a working session (the first phase of the learning task), and a teacher interview after the learning task was completed.

In practice, the video and live observations provided detailed information, both on the processes employed by the students in creating a business plan from start to finish, and on how the teacher supported them (e.g., learning activities and teacher-student interactions). The discussions and outputs produced in the learning environment were used to study the written collaboration between the teacher and the students, and among the students. A voice recording of a student pair's working session allowed the pair's 
work (the creation of a business plan) to be conducted not only at the school premises, but also at informal learning settings (the home of one of the students). The student pair carried out the recordings themselves. There were no breaks or significant offline discussions concerning the learning task. Finally, the teacher interview was used to uncover the teacher's interpretation of the students' learning processes during the creation of the business plan. The interview with the teacher was a theme interview. The themes concerned the implementation and results of the learning task, the working methods used, the role and tasks of the teacher, the utilization of the computer-supported learning environment, and the applicability of the learning task for the students in question. The various data collected served as a valuable tool to understand the hinderers and enablers of the collaboration process.

The analysis of the data was a multilayered process in which two main quality criteria were met. First, the findings clearly describe the different hinderers and enablers of the learning process. Second, the findings illuminate how learners' activities, the context and the teacher's instructional activities are interrelated with each other. The recorded teacher interview was transcribed first, and the transcription was then read thoroughly several times. The main elements that connected with the students' learning process were subsequently identified. Examples of the hinderers and enablers relating to these elements were sought by examining the data representing the actual implementation of the learning task. These data included the researcher's observations during the starting and closing sessions; the video recording of the starting session; the voice-recorded working session of one of the student pairs (during Phase 1 of the learning task); the written blogs of the four student pairs (Phase 1); the students' individually-written 
comments in the blog of an another student pair (Phases 2-3); and the teacher's and students' blog-based written collaboration (Phases 1-3) (see also Table 1.) The illustrations of both the enabling and hindrance factors related to the learning process are presented in Section 4. The data presented demonstrate the realities of implementing entrepreneurship education and developing transversal key competencies in iVET, and can assist in the future application of both entrepreneurship education and CSCL.

\section{Findings}

\subsection{A general overview}

The learning task of developing a business plan was project-like, problem- and practically-oriented and required learners to take different point of views (Hron and Friedrich 2003). The implementation of the task also included distance-learning (possibly at home) and asynchronous interaction, which require initiative and organization skills. In general, the students saw the creation of a business plan as a challenging task and there were difficulties in getting them involved. Only two students (who worked as a pair during Phase 1 of the task) carried out the task as planned, but the majority of the students (six in total) did not accomplish the task. Thus, the outcomes could have been more successful. This finding is in line with the critical findings of Dillenbourg and Jermann (2007), who noted that often in CSCL settings, there is a difference between the 'ideal' learning activities and the 'actual' (or realised) activities (i.e., what really happens). Concerning the realised activities, students commented in the closing session that they would have preferred to work alone. Moreover, the teacher saw that the complexity of the learning task hampered the students' performance. The teacher also 
added in the interview that learning based on social intercourse, dialogue and generating text is challenging for the students.

Well, a new type of task and therefore complicated, you know, although we may think it's quite clear. They [the students] might think it's, perhaps, multidimensional and find it difficult to grasp what's actually expected from them. (Teacher.)

Like I said, we had here quite a number of students whose background was in special education and there were others who clearly had some learning difficulties. A task of this type must have been very challenging for them. Producing text, you see, independently and learning based on dialogue in general seems, as a whole, to be quite a challenge.(Teacher.)

Concerning the learning task, the most successful outcome was the business plan by Jesper and Oskari, which was also the one chosen by the teacher as the best. The student pair who accomplished the plan collaborated for approximately one and a half hours during the first phase of the learning task, after which their business plan was as follows:

Our company is going to make home fixtures to order. We will make such fixtures exactly as the customers order them. We are able to make the products ourselves and have cooperated before as well. We will hire an expert as an accountant, and another to design the web pages, even if a web page is not absolutely necessary at the beginning. Also, for other so-called paperwork we might need some assistance, at the start at least. Our customers comprise everybody who is calling for our services. There are certainly many competitors out there, but our biggest asset is that we will make all our products ourselves, so although the price may be somewhat higher than for factory-made products, they will be of good quality and stylish for sure; besides, the value of a hand-made product will not drop. To begin with, we will need a fairly big loan in order to get appropriate premises, materials and machinery for the company.

Advantages:

- A precise and high-quality end result

- People appreciate hand-made products and pay more for them

- Skilled workers 


\section{Disadvantages:}

- A job may take a fairly long time to finish

- Material is expensive and much of it will go to waste

The plan presented above can be regarded as modest and brief regarding the actual establishment of the business; in other words, it can be seen as a kind of "dehydrated business plan” (Timmons and Spinelli 2009, 274) that provides the initial conception of the business and can be used to test the business idea. Even though the students' plan was brief, they managed to ponder the main questions on which they were instructed to take a stand (see Section 3.1). Of uppermost important is the information concerning the business idea, including the type and added value of their product (good-quality, handmade home furniture). They also considered the limits of their know-how and realised that they needed to outsource certain business operations (bookkeeping, web pages and some administrative issues). Moreover, they understood the extent of their investments at a general level. This plan was further developed by the teacher and the other students through their comments on the blog. Next, we will examine which factors hindered and enabled the implementation of the collaborative learning task.

\subsection{Hinderers of the learning task}

Concerning pair work, one of the pairs (Jesper and Oskari) was formed by the students themselves and the others were determined by the teacher. There were some difficulties with creating the predetermined pairs, in that two of the students who were present at the starting session were paired with students who were absent. Moreover, there was doubt even at the start about whether there would be successful collaboration, as evidenced by one student's statement below: 
'Well, that means that I will do it by myself and he just takes a back seat. It was like that [earlier] today.' (Student, male)

The somewhat challenging starting point for pair collaboration may have had a hindering effect on students’ working processes and completion of the task. Concerning the actual pair collaboration, the role of a 'companion', played by Jesper in this case, can be regarded as a hindrance of the process. This role was manifested so that Jesper was satisfied with less effort than his pair Oskari.

Oskari: You cannot, like, think of anything?

Jesper: Don't we already have everything there?

Oskari: Shall we put something like...

Jesper: A smiley?

Oskari: A summary. Yes, and then should it be like pluses and minuses there just like that? Get it?

Jesper: No.

Oskari: I mean the plus sides and the minus sides. Advantages and disadvantages. Jesper: Put it like that.

Oskari: Yes, just like that.

Jesper was also more often focussed on other things such as eating and making coffee than on the learning task. Thus, involvement in non-task-related issues was clearly present in the informal learning environment. Focus on non-task-related issues may not be regarded as a hindrance as such, but as a natural (and at its best, reflective) process in learning. Moreover, the learning task was found rather difficult by the student pair. Difficulty may not be a hindrance as such, but it tells at least that the task was not too easy.

Oskari: Er, my head is exploding.

[Jesper is eating and the boys are laughing] 
Jesper: This is just [swearing] difficult this [swearing] company thing.

Oskari: True. [...]

Regarding peer support, in the second and third phases of the learning task, students were asked to give each other development suggestions in relation to their business plans. This proved to be challenging. There was no collaborative dialogue; only a comment in the blog of another pair was asked for each student. Collaborative dialogue did not appear spontaneously, either. The only suggestions given, to get more education or to invent something brand new, were not especially beneficial forms of advice for novice entrepreneurs when creating their business plans. According to previous studies (e.g., Arvaja 2007), other students may nevertheless prove to be valuable learning resources for learners. However, in this case, the analysis of the collaboration effort indicated that little support was offered by the group. On the contrary, the teacher was obliged to point out that when someone 'throws in the towel,' it is easier for others to do the same. Thus, group collaboration may result in negative influences. Altogether, in this case, the interdependency of the student group appeared fragile, in that they did not take into account the consequences of their actions or failings on the work of the other students. (Boreham 2011; Kreijns, Kirschner and Jochems 2003.)

\subsection{Enablers of the learning task}

Several factors related to pair work acted as enablers of the learning process during the learning task. The pair work of Jesper and Oskari can be seen to reflect the two-fold core of successful entrepreneurship: 'art' and 'science' (Jack and Anderson 1999) or 'entrepreneurship' and 'management' (Davisson 2001, 63-64). The 
art/entrepreneurship component includes innovation, creativity and the discovery process, whereas the science/management component refers to business management and to the exploitation process (Davisson 2001, 63-64; Jack and Anderson 1999).

The first working session of Jesper and Oskari took half an hour, during which they focussed on identifying the business idea (discovery process). This session took place in a classroom directly after the starting session. Initially, it was Oskari who steered the pair's focus a number of times towards identifying the idea, as shown below:

Oskari: Well now, Jesper, let's try and think of something for this.

Jesper: A business plan, so basically, does it have to be, like, the field of construction or a carpenter?

Oskari: So there they are [refers to the task instructions]

Jesper: Construction carpenter, furniture carpenter ... Well, would it be this construction carpenter's industry? Think: fixtures, windows, doors and stairs.

Oskari: No, let's first think of what [the idea] is and then only after that we'll look at which [field] it will be. It doesn't really matter, as long as we come up with something worthwhile.

The pair pondered several business ideas before coming up with the one they chose to proceed with. Their business ideas included everything from (inside) jokes, such as wooden pizzas, to more realistic ideas, such as ready-made furniture sets, pain-relieving hooks, design chairs, window frames, work tables, school desks and TV sideboards. Their spectrum of fun-focussed ideas may have been somewhat restricted by the voice recording (data collection for the study), which helped to maintain their focus on the task. Finally, the pair decided to make custom-built home furniture. The spectrum of products they chose to produce was wider ranging than other product areas they had discussed.

In the second working session, the pair's focus was on the processes and tools for implementing the business idea in practice (management). This session lasted an hour and took place at Jesper's home. Oskari was responsible for typing up the plan on the 
computer. It can be seen that the working methods and the roles of the two students had an effect on how they completed the first phase of the task. During this phase, the focus of many of the other pairs was still at the level of listing contact information for the imaginary firm, while this pair managed to concentrate on the essentials and chose to proceed by answering the main questions relating to the business plan (see Section 3.1). The excerpt below shows how they considered their competitive edge:

Oskari: Ahem!

Jesper: Now what?

Oskari: [typing and reading aloud] We will make all our products ourselves, so ...

Oskari: What's like the advantage of that compared to something, how would you put it? You know, that one gets it like ready-made?

Jesper: Um.

Oskari: How would you put it: we will make our products ourselves...

Jesper: ...so our products are hand-made and of high quality for sure. Or something...

Oskari: Right, right! [typing and reading aloud] Although the price ...

Oskari: How should we put it, that in ready-made frames ...?

Jesper: Or like in factory-made products.

Oskari: Yes... [typing]

$\cdots$

Oskari: Like this?

Jesper: Like what? [reading aloud] There are certainly many competitors out there, but our biggest asset is that we will make all our products ourselves, so although the price may be somewhat higher than in factory-made products, they will be of good quality and stylish for sure; besides, the value of a hand-made product will not drop either.

Jesper: That was good!

Oskari: That was good!

Jesper: That was good!

In addition to focusing on the essentials, it was clear that the atmosphere during the pair collaboration affected whether the goals would be reached. The student pair shared jokes and laughed a lot at the funny elements they encountered when working on the task. Even if they both found the task difficult, their joking and laughing can be 
regarded as an indicator of a positive working atmosphere, which is an important factor of collaboration.

[Oskari is typing and the boys are joking, Jesper leaves the room and comes back after a while]

Oskari: [laughing] I can't think of anything here but minuses. It's just [swearing]. Let's just write 300 pages of minuses.

[the boys are laughing and discussing the food Jesper brought with him; Jesper is eating and joking]

Oskari: [typing and laughing] There we have our pluses.

Jesper: [reading aloud] Precise and high-quality end result.

Furthermore, it seems that the boys took on different roles and that the creation of knowledge was not always collaborative. Oskari played the role of 'the responsible one' and Jesper, 'the companion'. Oskari was in charge of the typing. He also brought the task forward.

Jesper: [shouting from the other room] Shall we have some coffee soon?

Oskari: I guess we could.

Jesper: [coming back into the room] Now! I'll make some.

Oskari: Yes, but let's do this first. This will take ten minutes.

Jesper: I'll switch the coffee machine on. Just a second. [Oskari laughing and Jesper leaving the room]

[Oskari writing]

Oskari was also focussed on the quality of the pair's output, tried to encourage his partner to achieve more, and was persistent .

Jesper: Now we must save it.

Oskari: Well it can be saved from here. I'll try to think of one more advantage. Now try to think of one advantage for us.

Jesper: Well, what ain't there?

Oskari: [reading aloud] Precise and high-quality end result; people appreciate hand-made items and pay more for them.

Oskari: What could still be like an advantage of ours? ... Skilled workers!

Jesper: um.

Oskari: [typing] Yes, this made it, buddy. 
Concerning peer support from the student group, the positive aspect was that three students gave development suggestions relating to the second and third phases of the learning task (see Table 1), and in this way assisted other students in positive achievements. During the second phase, a peer student, for example, constructively suggested that Jesper and Oskari could also restore items and, through that, support their main business operations of manufacturing custom-made home furniture. During the third phase of the learning task, development suggestions for the best business plan (the one of Jesper's and Oskari's) were given by three individual students from the viewpoints of a purchasing manager, a customer-service manager and a quality manager. These suggestions helped to develop the plan to a more specific level concerning different business operations. In previous studies, feedback from peers has been found to raise students' awareness of the audience's considerations, and to help students develop analytical and critical reading and writing skills (Storch 2005). The nature of the peer comments has also been found to differ from the comments given by the teacher, with peer comments seen to be less formal and easier to reject, among other things (Rollinson 2005).

The support given by the teacher was during the first phase of creating the business plan, based on written, blog-based dialogues between the teacher and the students. The teacher monitored and guided the work of the pairs through the Internet. When the teacher registered clear problems with the business idea, he tried to guide the students to rethink their idea. However, students did not always respond to his rethinkingprovoking efforts. In cases where the teacher regarded the business idea as operable, he helped the students to consider and clarify the essential issues related to establishing the 
business. In the following example, the teacher's comments and questions provoked a collaborative and constructive dialogue with the student pair Jesper and Oskari, and through which helped the pair to ponder further the quality of the products, the expenses, the specifics of the working equipment, and the business premises.

Teacher: This plan shows a clear effort already. A few questions come to mind right away: Is the product quality sufficient, given your experience, that you can ask a higher price than for serially manufactured products? What kind of machinery did you describe? Please post a list of machines that you will absolutely need in the beginning. How much would the set cost in euro? The issue of premises: How much space would you need (square metres)? How much would the rent for such a premises be per month, or were you planning to buy one?

Student [representing the pair]: Answer to Mikko [the teacher]: In the beginning we could well make furnishings from ready-made frames besides handicraft, and see if it is profitable. On the prices, you could do a general survey, for instance, and talk to an expert. Regarding initially necessary machinery,... [...responding to all the questions....]

Teacher: Good answers. Let's see if we get any comments from the others. [...writing about the space the business requires....]

Concerning the teacher's support, besides offering the students guidance in person before the task and through written comments in the learning environment during the task, students also had the opportunity to ask for help at any time, be it through the learning environment, in person, by phone or by e-mail. The teacher also used Facebook to remind students about the deadlines.

\section{Conclusions}

In general, there is a growing global demand to enhance entrepreneurship in the context of iVET. In this case study, entrepreneurship education was examined on the basis of making a business plan in the context of a specific profession. That theme has 
been identified as one of the major areas for improvement with respect to integrating entrepreneurship in education (European Commission, Enterprise and Industry Directorate-General 2009). Moreover, there is a shortage of research-based knowledge on enhancing entrepreneurship-related skills in iVET. The outcome of this study provides a better understanding of the factors that hinder and enable collaborative learning in the context of entrepreneurship in iVET. In practice, nine dimensions of descriptive factors that hindered the exercise and nine distinct descriptive factors that acted as enablers were identified. Table 2 presents the hinderers and the enablers of collaborative learning in relation to pair collaboration and support from the teacher and student group. This table highlights that the key factors relate positively and negatively to the dynamics between the pairs, features of the student group, and the support given by the teacher.

TABLE 2: Hinderers and enablers of CSCL in iVET

\begin{tabular}{|c|c|c|}
\hline Key factor & Hinderers & Enablers \\
\hline $\begin{array}{l}\text { Collaboration } \\
\text { in pairs }\end{array}$ & $\begin{array}{l}\text { - Non-collaborative knowledge } \\
\text { construction } \\
\text { - Pair creation: an absent or } \\
\text { undesirable pair } \\
\text { - Absence of collaboration } \\
\text { - Intervening matters inherent in } \\
\text { the informal learning } \\
\text { environment }\end{array}$ & 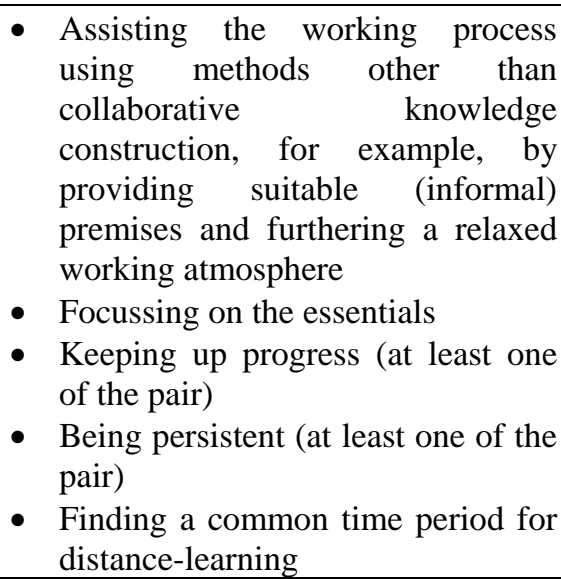 \\
\hline Other support & $\begin{array}{l}\text { - Non-specific or non-constructive } \\
\text { - Nomments from the student group } \\
\text { collaborative dialogue between } \\
\text { the students in the group } \\
\text { - The students not reacting to the } \\
\text { guidance of the teacher } \\
\text { - Total absence of supportive } \\
\text { collaboration among the students }\end{array}$ & $\begin{array}{l}\text { - Supportive and specific comments } \\
\text { from the student group } \\
\text { - Monitoring and guidance } \\
\text { (comments, suggestions and } \\
\text { clarifying questions) by the teacher } \\
\text { via the learning environment } \\
\text { - Collaborative and constructive } \\
\text { written dialogue between the } \\
\text { student pair and the teacher aided }\end{array}$ \\
\hline
\end{tabular}




\begin{tabular}{|c|c|c|c|}
\hline & & $\begin{array}{l}\text { in the group } \\
\text { - Copying the negative } \\
\text { performance of other students in } \\
\text { the group (e.g., not doing the } \\
\text { task) }\end{array}$ & $\begin{array}{l}\text { by the teacher's guidance via the } \\
\text { Internet } \\
\text { - Specific comments from the } \\
\text { student group }\end{array}$ \\
\hline
\end{tabular}

Due to the nature of case studies, the findings of this study are limited and cannot be directly generalized (Corbin and Strauss 2008; Avraamidou 2014). However, being aware of these factors helps the education system in its task of exposing students to entrepreneurship as a career option (Onstenk 2003; European Centre for the Development of Vocational Training 2011), and aiding teachers in integrating entrepreneurship education, such as making a business plan, into the syllabuses.

The findings indicated that the factors which hindered the successfulness of collaborative learning included absent or inadequate commenting by peers, lack of spontaneous dialogue, negative influence of students who did not apply themselves to the task, and remote reactions to the guidance offered by the teacher. The hindrances which were present, particularly in connection with pair collaboration, included noncollaborative knowledge construction, absence of collaboration, and difficulties with pair creation. Our findings are in line with the notion that learners with limited successful collaborative experiences may not be able to collaborate effectively (Fischer et al. 2013). The student pair also found their shared task difficult. Hence, the cognitive load of the pair task may have been too extensive to be shared between just two persons (Kirschner, Paas and Kirschner 2009). Moreover, according to the teacher, the general difficulties with the collaborative learning task may have been connected with the complexity of the learning task. This result is in contrast to evidence from previous studies that demonstrate the effectiveness of the complexity of the learning task as an important factor for 
successful collaborative learning (Kirschner, Paas and Kirschner 2009). Therefore, designing the complexity of the CSCL learning task seems to be a challenging process that balances between being simple enough that it can be done, and yet offering sufficient complexity. The variations in the successful task structure may relate to the learning contexts. According to Hämäläinen and De Wever (2013) CSCL studies have typically focused on contexts other than vocational education (e.g., higher education). Thus, this study gives indication that research findings from other educational contexts may not be directly transferable to the VET practices. In the future, it will be important to find more knowledge on how to design CSCL for VET. At its best, CSCL can add value to vocational learning (e.g. Minnaert et al. 2011).

Based on our findings, there were factors that enabled collaboration. Specifically, factors related to positive interaction acted as essential enablers of collaborative learning. These included enhancement of the working process by collaborative means other than actual collaborative knowledge construction; for example, through the promotion of a relaxed working atmosphere, focusing on the essentials of the task, keeping up progress, being persistent, and arranging suitable times for distance-learning. Specifically, the findings of this study highlight that pair collaboration involves more than just knowledge construction and working with a given task; it is also about supporting the working process through creating a positive atmosphere (e.g., Jesper and Oskari joking and laughing together) and fostering a workable learning environment. Additionally, the findings of this study illuminate that the flexibility of the script allowed peer collaboration that enabled different kinds of business solutions. With respect to this, one can see similarities with the notion of positive effect resulting from flexibility in scripting 
for CSCL, as noted by Dillenbourg (2002). Additionally, our findings illustrate that enablers, linked with support from the student group and teacher, encompassed supportive and reasonably specific commenting by the group (e.g. the developmental viewpoints of a purchasing manager, a customer-service manager and a quality manager given by the peers); guidance given by the teacher; and a collaborative, constructive written dialogue between the student pair and the teacher in the learning environment.

The results also show that making a business plan may be challenging for youths who are just becoming familiar with their future field of business. Our example on pair work illustrates that, although the script of the learning task created settings for collaborative learning, the positive style of working together sealed the successfulness of the exercise. Additionally, the findings illuminate that, for teenage students, it may be difficult to take the initiative and be responsible for the progress of their work. In this case, the teacher's comments and questions were able to provoke a collaborative and constructive dialogue with the student pair. Therefore, the teacher's support cannot be underestimated, even in terms of tasks based on distance-learning. Altogether, our findings reveal that the development of VET calls for research-based pedagogical approaches, in which entrepreneurial skills are enabled and fostered to meet the changing needs of today's work environment. 


\section{REFERENCES}

Ardichvili A., Cardozo R. and Ray S. 2003. "A theory of entrepreneurial opportunity identification and development.” Journal of Business Venturing 18 (1): 105-123.

Arvaja, M. 2012. "Personal and shared experiences as resources for meaning making in a philosophy of science course." International Journal of Computer-Supported Collaborative Learning 7 (1): 85-108.

Arvaja, M. 2007. "Contextual perspective in analysing collaborative knowledge construction of two small groups in web-based discussion." International Journal of Computer-Supported Collaborative Learning 2 (2-3): 133-158.

Attwell, G. 2007. "Personal Learning Environments - the future of eLearning?.” eLearning papers 2 (1). http://www.elearningeuropa.info/files/media/media11561.pdf.

Avraamidou, L. 2014. "Tracing a beginning elementary teacher's development of identity for science teaching.” Journal of Teacher Education 65 (3): 223-240.

Bangs, D. H., Jr. 2002. Business Planning Guide: Creating a Winning Plan for Success, $9^{\text {th }}$ ed. Chicago: Dearborn Trade Publishing. A Kaplan Professional Company.

Boreham, N. 2011. "Competence as Collective Process.” In Vocational Learning: Innovative Theory and Practice, edited by Ralph Catts, Ian Falk and Ruth Wallace, 7791. London: Springer Dordrecht.

Corbin, J. M. and Strauss, A. L. 2008. Basics of Qualitative Research: Techniques and Procedures for Developing Grounded Theory, $3^{\text {rd }}$ ed. Thousand Oaks, CA: Sage Publications, Inc..

De Wever, B., Hämäläinen, R., Voet, M. and Gielen, M. 2015. “A wiki task for first-year university students: The effect of scripting students' collaboration.” The Internet and Higher Education. 25: 37-44.

Dillenbourg, P. 2002. "Over-scripting CSCL: The risks of blending collaborative learning with instructional design.” In Three Worlds of CSCL. Can We Support CSCL? edited by P. A. Kirschner, 61-91. Heerlen, Netherlands: Open Universiteit Nederland. http://hal.archives-ouvertes.fr/hal-00190230/.

Dillenbourg, P. and Jermann, P. 2007. "Designing integrative scripts." In Scripting Computer-Supported Collaborative Learning: Cognitive, Computational and Educational Perspectives edited by Frank Fischer, Ingo Kollar, Heinz Mandl, and Jörg M. Haake, and I. Kollar, 275-301. New York: Springer US. 
European Centre for the Development of Vocational Training (Cedefop). 2011. Guidance supporting Europe's aspiring entrepreneurs: Policy and practice to harness future potential. Luxembourg: Publications Office of the European Union.

European Commission/EACEA/Eurydice. 2012. "Developing key competencies at school in Europe: Challenges and opportunities for policy." Eurydice Report 2011/12. Luxembourg: Publications Office of the European Union.

European Commission, Enterprise and Industry Directorate-General. 2009. Entrepreneurship in Vocational Education and Training. Final Report of the Expert Group.

Fischer, F., Kollar, I., Stegmann, K. and Wecker, C. 2013. "Toward a script theory of guidance in computer-supported collaborative learning.” Educational Psychologist 48 (1): 56-66.

Gibb, A. 2000. "Corporate restructuring and entrepreneurship: What can large organizations learn from small?” Enterprise \& Innovation Management Studies 1 (1): 19-35.

Gibb, A. 2005. "The future of entrepreneurship education - Determining the basis for coherent policy and practice." In The Dynamics of Learning Entrepreneurship in a Cross-Cultural University Context, edited by Paula Kyrö and Camille Carrier, 44-68. Tampere, Finland: University of Tampere, Faculty of Education, Research Center for Vocational and Professional Education.

von Graevenitz, Harhoff, D. \& Weber, R. 2010. "The effects of entrepreneurship education.” Journal of Economic Behavior \& Organization 76(1), 90-112.

Heinonen, J. and Poikkijoki, S-A. 2006. “An entrepreneurial-directed approach to entrepreneurship education: Mission impossible?” Journal of Management Development 25 (1): 80-94.

Honig, B. 2004. "Entrepreneurship education: Toward a model of contingency-based business planning.” Academy of Management Learning and Education 3 (3): 258-273.

Hron, A. and Friedrich, H. F. 2003. "A review of web-based collaborative learning: Factors beyond technology.” Journal of Computer Assisted Learning 19 (1): 70-79.

Hämäläinen, R. and De Wever, B. 2013. "Vocational education approach: New TEL settings-new prospects for teachers' instructional activities?” International Journal of Computer-Supported Collaborative Learning 8 (3): 271-291.

Hämäläinen, R. and Häkkinen, P. 2010. “Teachers’ instructional planning for computersupported collaborative learning: Macro-scripts as a pedagogical method to facilitate collaborative learning.” Teaching and Teacher Education 26 (4): 871-877. 
Hämäläinen, R. and Vähäsantanen, K. 2011. “Theoretical and pedagogical perspectives on orchestrating creativity and collaborative learning." Educational Research Review 6 (3): 169-184.

Jack, S. L. and Anderson, A. R. 1999. "Entrepreneurship education within the enterprise culture: Producing reflective practitioners.” International Journal of Entrepreneurial Behaviour \& Research 5 (3): 110-125.

Kirby, D. 2007. "Changing the entrepreneurship education paradigm.” In Handbook of Research in Entrepreneurship Education, Volume 1: A General Perspective, edited by Alain Fayolle, 21-45. Cheltenham, UK: Edward Elgar Publishing Limited.

Kirschner, F., Paas, F. and Kirschner, P. A. 2009. "A cognitive load approach to collaborative learning: United brains for complex tasks.” Educational Psychology Review 21 (1): 31-42.

Kobbe, L., Weinberger, A., Dillenbourg, P., Harrer, A., Hämäläinen, R., Häkkinen, P. and Fischer, F. 2007. "Specifying computer-supported collaboration scripts." International Journal of Computer-Supported Collaborative Learning 2 (2-3): 211-224.

Krange, I. and Ludvigsen, S. 2008. "What does it mean? Students' procedural and conceptual problem solving in a CSCL environment designed within the field of science education.” International Journal of Computer-Supported Collaborative Learning 3 (1): 25-51.

Kreijns, K., Kirschner, P. A. and Jochems, W. 2003. "Identifying the pitfalls for social interaction in computer-supported collaborative learning environments: A review of the research.” Computers in Human Behaviour 19 (3): 335-353.

Leffler, E. 2009. “The many faces of entrepreneurship: A discursive battle for the school arena.” European Educational Research Journal 8 (1): 104-116.

Liñán, F. 2007. “The role of entrepreneurship education in the entrepreneurial process.” In Handbook of Research in Entrepreneurship Education. Volume 1: A General Perspective, edited by Alain Fayolle, 230-247. Cheltenham, UK: Edward Elgar Publishing Limited.

Mercer, N., Dawes, L., Wegerif, R. and Sams, C. 2004. "Reasoning as a scientist: Ways of helping children to use language to learn science.” British Educational Research Journal 30 (3): 359-377.

Minnaert, A., Boekaerts, M., de Brabander, C. and Opdenakker, M-C. 2011. "Students' experiences of autonomy, competence, social relatedness and interest within a CSCL environment in vocational education: The case of commerce and business administration." Vocations and Learning 4 (3): 175-190. 
Neck, H.M. \& Greene, P.G. 2011. "Entrepreneurship education: Known worlds and new frontiers.” Journal of Small Business Management 49(1), 55-70.

O’Bannon, B. W., Lubke, J. K. and Britt, V. G. 2013. “'You still need that face-to-face communication': Drawing implications from preservice teachers' perceptions of wikis as a collaborative tool.” Technology, Pedagogy and Education 22 (2): 135-152.

Onstenk, J. 2003. “Entrepreneurship and vocational education.” European Educational Research Journal 2 (1): 74-89.

Rollinson, P. 2005. "Using peer feedback in the ESL writing class” ELT Journal 59 (1): 23-30.

Ruiz-Primo, M. A., Figueroa, M., and Gluckman, M. 2011. "Exploring small group processes and their impact on student learning in the context of inquiry-based science instruction." Paper presented at the meeting of the American Educational Research Association (AERA), New Orleans, Louisiana, April 8-12.

Shaughnessy, J. J., Zechmeister, E. B. and Zechmeister, J. S. 2002. Research Methods in Psychology, 5/e. New York: The McGraw-Hill Companies. http://www.mhhe.com/socscience/psychology/shaugh/index.html.

Stake, R. E. 2005. “Qualitative Case Studies.” In The Sage handbook of qualitative research, $3^{\text {rd }}$ ed., edited by Norman K. Denzin and Yvonna S. Lincoln, 443-466. Thousand Oaks, CA: Sage Publications, Inc.

Storch, N. 2005. “Collaborative writing: Product, process, and students' reflections." Journal of Second Language Writing 14 (3): 153-173.

Strijbos, J-W. and De Laat, M. F. 2010. "Developing the role concept for computersupported collaborative learning: An explorative synthesis." Computers in Human Behavior 26 (4): 495-505.

Timmons, J. A. and Spinelli, S. 2009. New venture creation: Entrepreneurship for the $21^{\text {st }}$ century, $8^{\text {th }}$ ed. New York: McGraw-Hill/Irwin.

Tsovaltzi, D., Puhl, T., Judele, R. and Weinberger, A. 2014. "Group awareness support and argumentation scripts for individual preparation of arguments in Facebook." Computers \& Education 76: 108-118.

Tynjälä, P. 2013. "Toward a 3-P model of workplace learning: A literature review.” Vocations and Learning. Studies in Vocational and Professional Education 6 (1): 11-36.

Yin, R. K. 2003. Applications of Case Study Research, $2^{\text {nd }}$ ed. Thousand Oaks, CA: Sage Publications, Inc. http://books.google.com/books?id=Ht8m44CA3YIC\&pgis=1. 